\title{
MINERAL PELLICLES ON THE LAKES SURFACE OF WARM AND COLD ZONES IN KUNGUR ICE CAVE
}

\author{
MINERALNE SKORJE NA POVRŠINI JEZER V TOPLIH \\ IN HLADNIH CONAH KONGURSKE LEDENE JAME
}

Ilya TCHAIKOVSKIY ${ }^{1}$, Olga KADEBSKAYA ${ }^{1}$ \& Tatyana KALININA $^{1}$

\begin{abstract}
UDC 551.444.4:549(470+571)

551.44:551.581(470+571)

Ilya Tchaikovskiy, Olga Kadebskaya \& Tatyana Kalinina: Mineral pellicles on the lakes surface of warm and cold zones in Kungur ice cave

Investigation of mineral pellicles formed at the surface of ponds in Kungur Ice Cave showed their structure and formation mechanism to depend on location in a cold or warm microclimatic zone. In spite of identical initial chemical composition of solutions, infiltrated through carbonate-sulfate massif, different climatic zones are characterized by specific order of mineral crystallization on the water surface. The revealed difference is related to various climatic conditions and solution supersaturation mechanisms. Mineral pellicles formed in different microclimatic zones are described in the article.

Keywords: Cryominerogenesis, caves microclimatic zones, mineral climate indicators.
\end{abstract}

Izvleček

UDK 551.444.4:549(470+571)

551.44:551.581(470+571)

Ilya Tchaikovskiy, Olga Kadebskaya \& Tatyana Kalinina: Mineralne skorje na površini jezer $v$ toplih in hladnih conah Kongurske ledene jame

Raziskava mineralnih skorij rastočih na površini jezer v Kongurski ledeni jami kaže povezavo med njihovo strukturo in mehanizmom nastanka ter lokacijo $\mathrm{v}$ hladnem ali toplem mikroklimatskem območju jame. Kljub enaki kemični sestavi infiltrirane raztopine skozi karbonatni masiv, so različna mikroklimatska okolja $\mathrm{v}$ jami okarakterizirana $\mathrm{z}$ značilnim vrstnim redom kristalizacije mineralov na vodni površini. Zaznana razlika je povezana $\mathrm{z}$ različnimi klimatskimi pogoji in mehanizmi prenasičene raztopine. Mineralne skorje nastale $\mathrm{v}$ različnih mikroklimatskih conah so opisane v članku.

Ključne besede: Krio-mineralogeneza, jamske mikroklimatske cone, mineralni inikatorji klime.

\section{INTRODUCTION}

Kungur Ice Cave is a system of horizontal passages with few entries at different altitudes. Single flour of the cave is situated along the one level about $111-112 \mathrm{~m}$ that is close to water level in the Sylva River. Cave length is about $5.7 \mathrm{~km}$, the area $-65000 \mathrm{~m}^{2}$, the amplitude $-32 \mathrm{~m}$. There are three microclimatic zones in the cave (Fig. 1) which are distinguished by different temperatures: 1) permanently negative temperature (cold zone), 2) permanently positive temperature (warm zone), 3) fluctuating temperature (transition zone) (Tchaikovsky \& Kadebskaya 2009).
Cave air flows upward in the cold season and it flows downward in the warm season. The upward (winter) air circulation appears in autumn at the outside temperature below $5{ }^{\circ} \mathrm{C}$ and the downward (summer) one - at the outside temperature above $5^{\circ} \mathrm{C}$.

Negative temperatures preserve during all year in the negative temperature anomaly (cold) zone that is favourable for perennial ice formation. Permanent glaciation boundary is situated along the northern part of Krestovy and eastern part of Zapadny Grottos (at a distance of about $200 \mathrm{~m}$ from the entrance) whereas sea-

\footnotetext{
${ }^{1}$ Mining Institute of Ural Branch of Russian Academy of Sciences - Sibirskaya78a - 614007 Perm, Russia;

e-mail: tatyanaak89@mail.ru
}

Received/Prejeto: 01.07.2013 


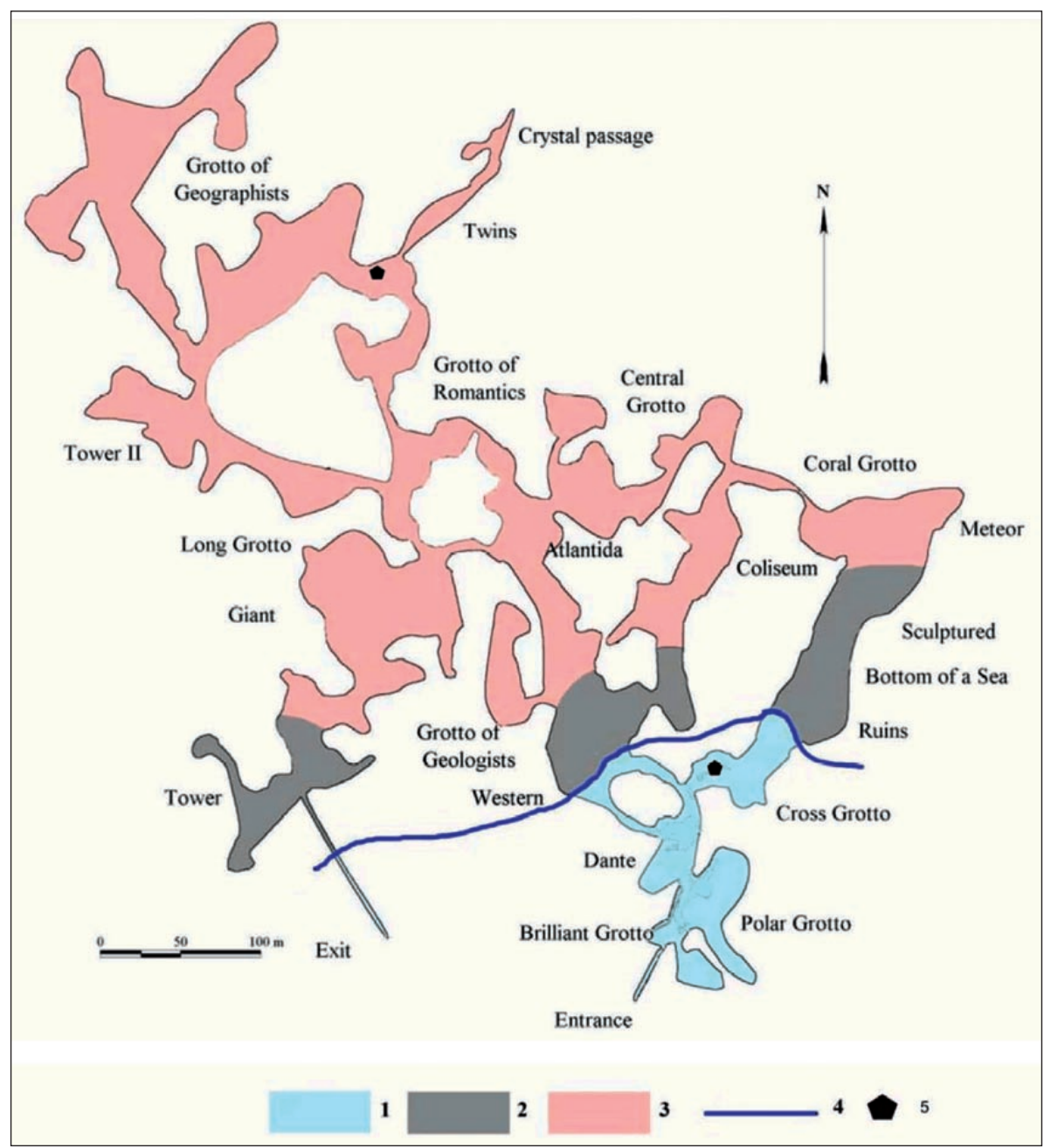

Fig. 1: Microclimatic zones in the Kungur Ice Cave: 1 - permanently negative temperature (cold zone), 2 - fluctuating temperature (transition zone), 3 - permanently positive temperature (warm zone), 4 - perennial glaciation boundary; 5 - sampling points.

sonal glaciation boundary is situated along Morskoye Dno, Geologov and Smelykh Grottos.

The warmest period with temperatures $0{ }^{\circ} \mathrm{C}<\mathrm{t}<3{ }^{\circ} \mathrm{C}$ begins in April and last until October-November in transition zone in dependence on temperature sign changeover outside of the cave. Seasonal ice forms in transition zone in Vyshka, Ruins, Morskoye Dno, Smelykh and Zapadny Grottos in winter (December-March). We should also add boundary parts of perennial ice in Scandinavsky and Polar Grottos to transition zone, but the warm period here is much shorter - only two-three months in year (September-November).

There is cave protected area (Druzhby Narodov, Romantics, Dlinny, Coliseum Grottos and others) in the neutral zone of the cave with virtually constant temperatures about $5-6^{\circ} \mathrm{C}$.

\section{METHODS}

Microcrystals located in a micro-reservoir on the surface perennial ice were fixed in cold zone of Kungur Ice cave in spring of 2010. They remained on microreservoir surface at the expense of superficial tension. Water completely frozen in summer and mineral units appeared inside the ice. These pellicles were released from ice at the expense of ice evaporation and they laid free on the surface in winter of 2011 (Fig. 1). Such pellicles from Krestovy Grotto were selected for studying.

Mineral pellicles from warm part of the cave which represent druzy aggregate of acuminate rhombohedral 
calcite crystals were selected from the lake surface in Bliznetsy Grotto (Fig. 1).

Selected samples study was carried out under binocular microscope and analytical scanning electron mi- croscope VEGA 3 TESCAN with system of the $\mathrm{x}$-ray power dispersive microanalysis INCA Energy 350/Xmax 20 (the analyzer is Elena Chirkova).

\section{RESULTS}

\section{MINERAL PELLICLES OF COLD ZONE}

Temperature observations were carried out in 2010 at the entrance, in Krestovy (zone of negative temperature anomalies) and Bliznetsy Grottos (neutral zone) (Fig. 2). Infiltration water from the organ pipe in Krestovy Grotto began to flow on surface of multi-year ice in April. Depth of layer of water on the surface of ice reached $10 \mathrm{~cm}$. According to measurements on the reference set in this part of ice, the growth of ice from April to November was $16 \mathrm{~cm}$. Water layer during this time was freezing slowly. Ice formation occurred in the lower part of water layer adjacent to the ice. Air temperature in Krestovy grotto in April was $-1.1{ }^{\circ} \mathrm{C}$, it gradually increased to $0.3^{\circ} \mathrm{C}$ then and remained at this level until November. Water pellicle was completely frozen in December.

Study of morphology of selected pellicles showed that they represent drusy aggregate of well-formed crystals of gypsum and calcite, which grew down from water surface. Traces of air bubbles as well as inclusions of allophanite spherules and clastic grains of calcite are often marked on the top of surface (Fig. 3).

Gypsum is presented by platy crystals (up to $100 \mu \mathrm{m}$ ) formed by plane-face individuals as well as complicated growth elements: boxy and costal crystals (Fig. 3.4).

Calcite fills gaps between clusters of gypsum crystals and grows on their surface (Fig. 3.5). It is marked as single crystals or divergent clusters. Its composition is persistent and describes by trace impurities of magne- sium (up to 3.65 at. \%), strontium (up to 0.21 at. \%) and sodium (up to 1.5 at. \%). Single crystal of gaylussite has been also specified, which chemical composition corresponds to evaluation formula $\mathrm{Na}_{1.98} \mathrm{Ca}_{1.02}\left(\mathrm{CO}_{3}\right)_{2} \cdot 5 \mathrm{H}_{2} \mathrm{O}$.

Presence of air bubbles traces and inclusions (allophanite, calcite) of silt (3-60 $\mu \mathrm{m})$ dimension on mineral pellicles suggests that they acted as a seed for crystallization of newly formed phases. Implementation of calcite interstice and its growth on individuals of gypsum reflects the after crystallization of calcium sulphate. Frequent occurrence of gypsum crystals in boxy, rarer costal forms, as well as presence of merohedric impurities of magnesium, strontium and sodium in calcite reflect rapid disordered crystallization of these minerals, probably associated with strong saturation due to frosting of water layer on the surface of ice and accumulation of salts in liquid phase. Formation of water of carbonate - gaylussite - may be evidence of conditions close to cryogenic.

\section{MINERAL PELLICLES OF WARM ZONE}

Temperature in Bliznetsy grotto holds practically constant during the year and was in the period of mineral pellicles formation from 4.9 to $5.1^{\circ} \mathrm{C}$ (Fig. 2). Pellicles were selected in the summer low-water period, when lake level was minimal, and its surface was covered by almost continuous layer of crystalline formations (Fig. 4). In marginal parts of the lake some of pellicles have dried up and laid free on large fragments of gypsum and clay.

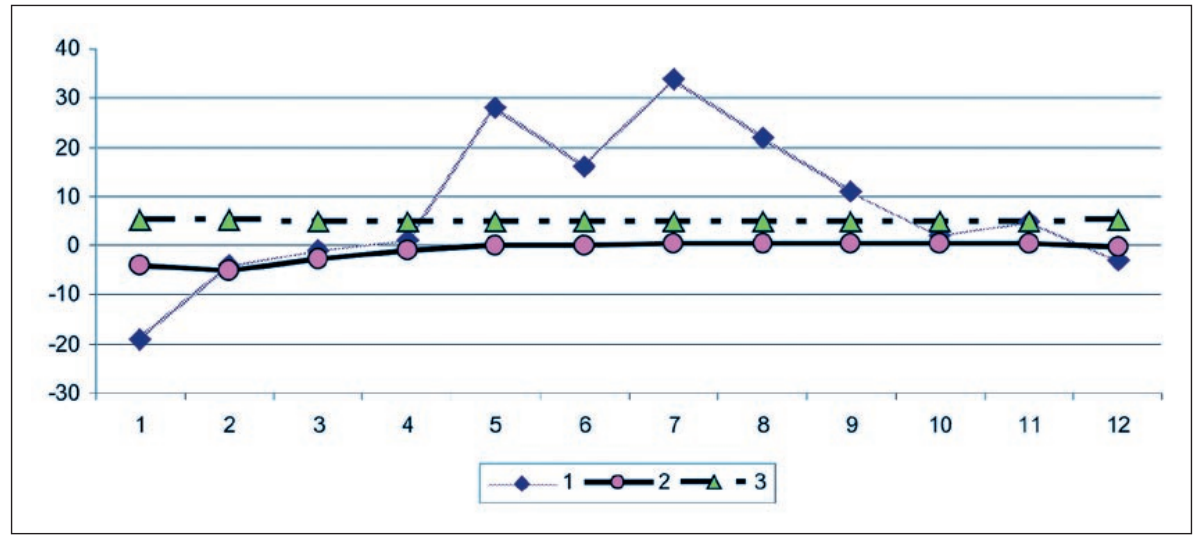

Fig. 2: The annual course of air temperature 1 - at the entrance to the cave, 2 - Krestovy grotto (zone of negative temperature anomalies), 3 - Bliznetsy grotto (neutral zone). 


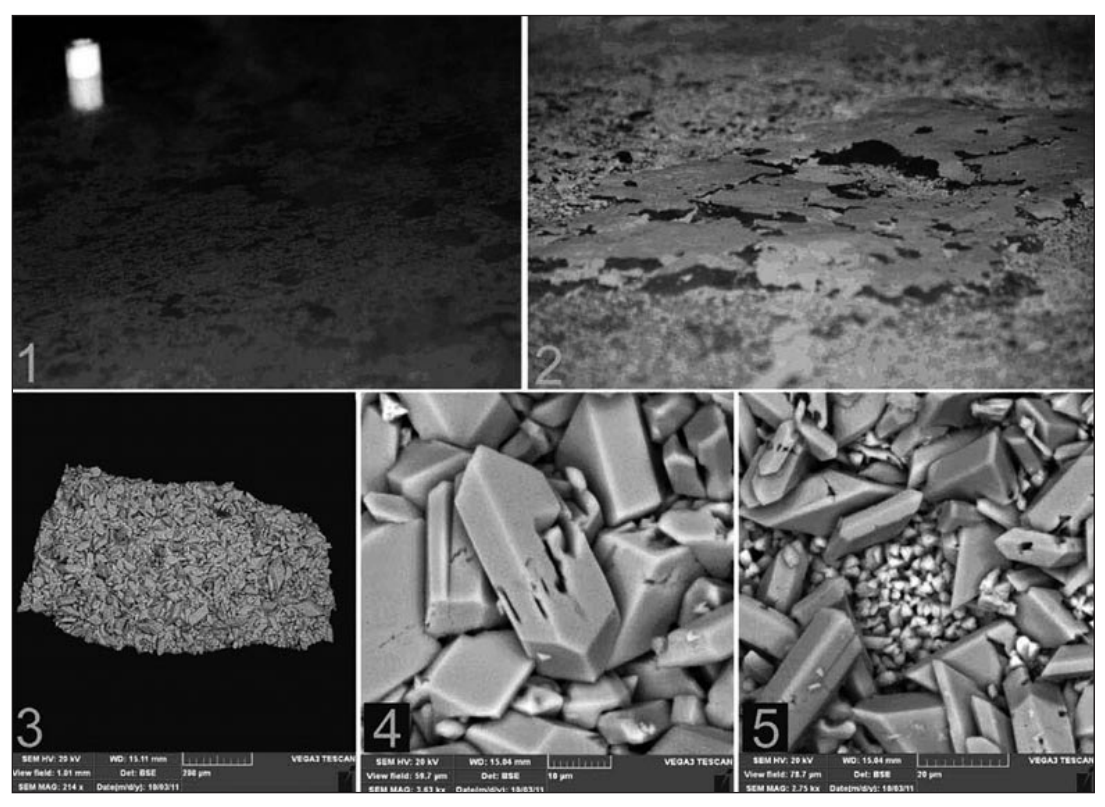

Fig. 3: Mineral pellicles of cold zone: 1 - clusters of microcrystals floating on the surface of water layer (April, 2010), 2 - fragments of gypsum crusts over ice surface (December, 2010); 3-5 - general view and details of structure of mineral pellicles (crystals of gypsum (4) and located between them individuals of calcite (5).

Study of mineral pellicles from the surface of lake in Bliznetsy grotto from warm part of the cave showed that they represent druzy aggregate of acuminate rhombohedral crystals of calcite (Fig. 5).

It is noted that larger crystals compose separate clusters on the surface of druse as well as marginal parts of mineral crusts. Both small and large individuals are complicated by split.

Occasionally other minerals (celestine, magnesian calcite, dolomite, gypsum, halite) are observed, which are fixed at the outside of mineral pellicles in nests between calcite crystals (Fig. 5.4-5.6).

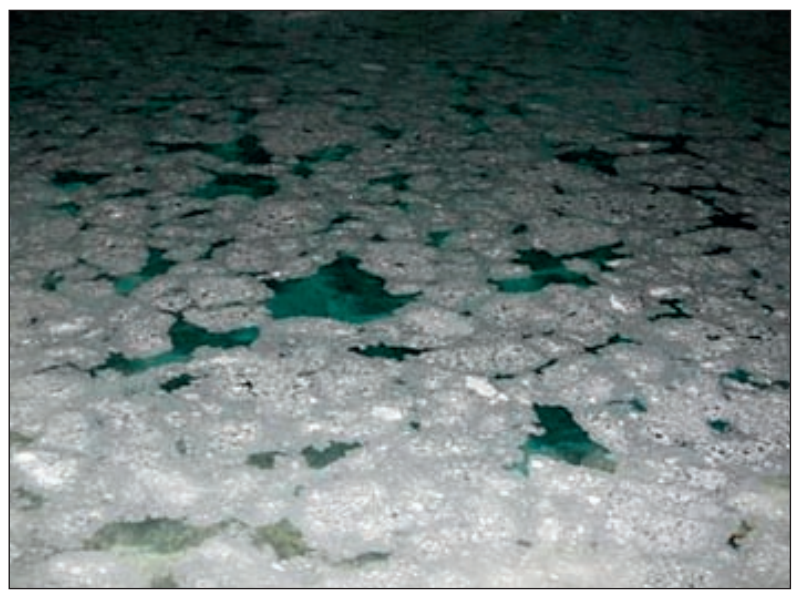

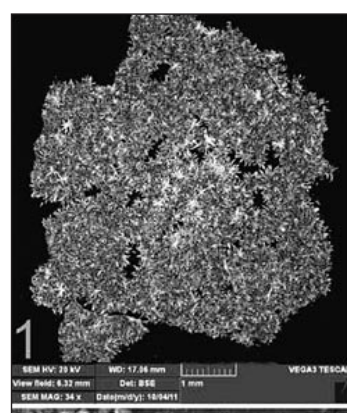
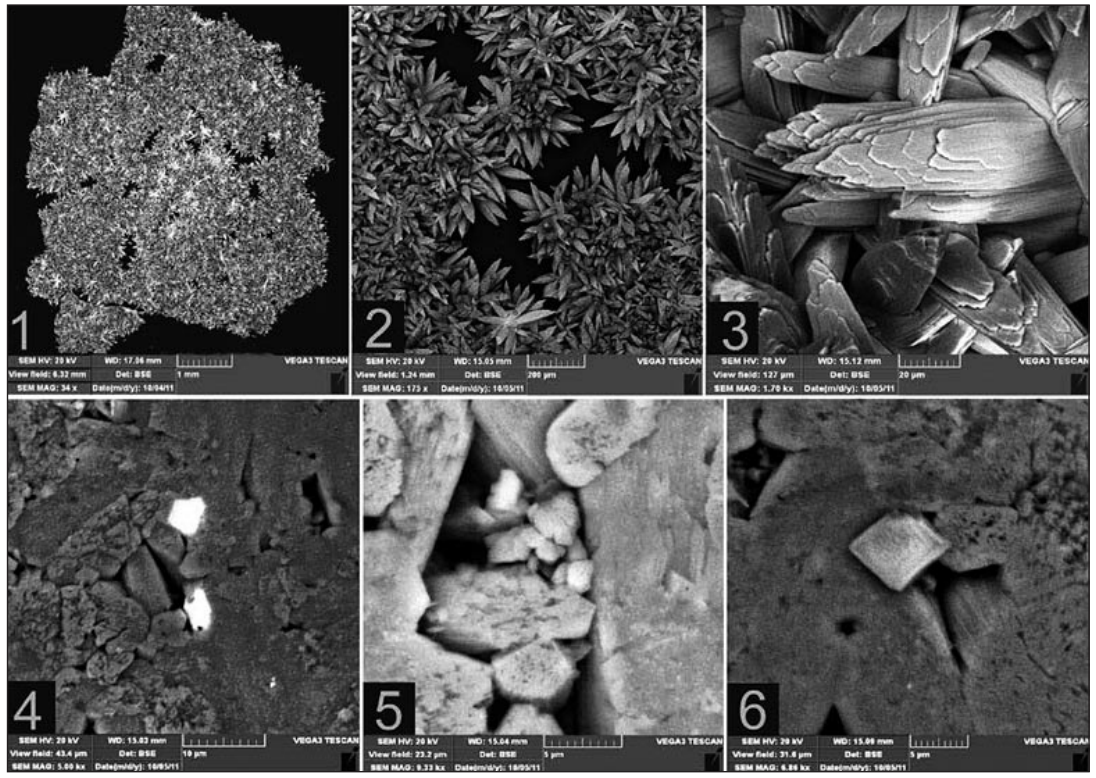

Fig. 4: Mineral pellicles on the surface of lake in neutral zone of Kungur Ice cave.
Fig. 5: Mineral pellicles of warm zone: 1-3 - general view and details of structure of calcite pellicle; 4-6 - celestine, gypsum, dolomite and halite crystals. 


\section{DISCUSSION}

Study of chemical composition of calcite and celestine showed absence of significant isomorphic impurities. However, carbonates of mineral pellicles of cold and warm zones comparison showed (Fig. 6) that the first ones are characterized by accumulation of sodium (up to gaylussite) and magnesium (up to magnesian calcite), and the second ones - only magnesium (up to dolomite).

Formation of calcite aggregates only on the surface of pond in warm zone suggests that saturation of solutions and mineralization occurs only in the surface layer of water. Deposition of calcite could be due to decomposition of soluble bicarbonate by evaporation of carbon dioxide from the surface of lake. Crystals split, as well as association of large individuals with the edge parts of mineral crusts indicates significant effects of fractionation of carbon dioxide on the solution saturation. Hill \& Forti (1997) described a similar mechanism of formation of the floating mineral pellicles (rafts) in caves. Formation of other minerals may be due to micro-reservoirs which are formed on the surface of carbonaceous pellicles in the interstice between calcite crystals and are not associated with the lake. Their evaporation leads to highly mineralized brines formation from which evaporite complex minerals crystallize (dolomite, gypsum, halite).

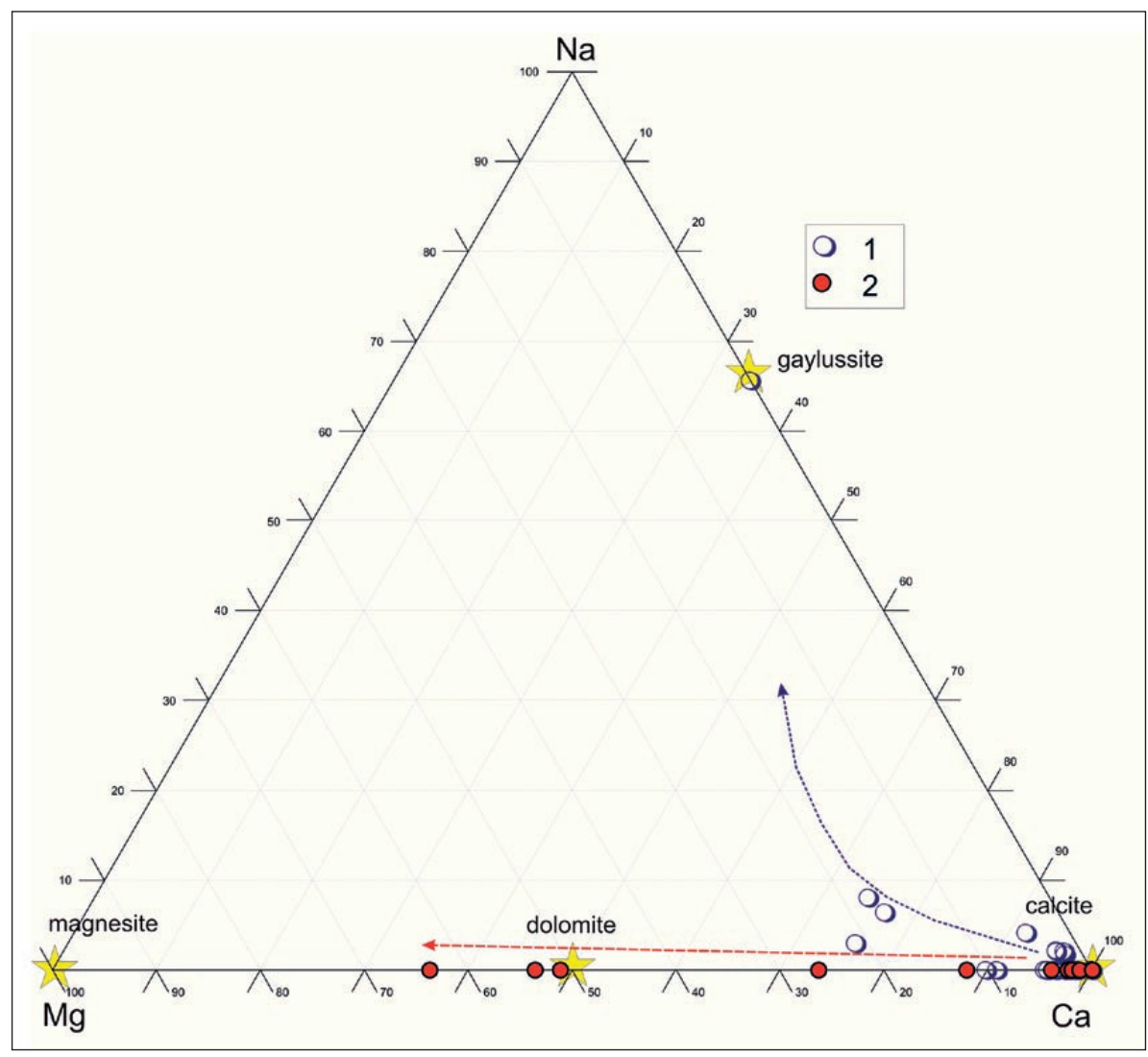

Fig. 6: Ratio of $\mathrm{Ma}-\mathrm{Ca}-\mathrm{Na}$ (atom. number) in carbonates of cold (1) and warm (2) zones. Asterisks show normative compositions of minerals, arrows - expected trends of structure evolution in process of freezing and evaporation.

\section{CONCLUSIONS}

Thus, two different types of floating mineral pellicles form on the water surface in Kungur Ice cave.

In cold area highly gypsum pellicles, recovered with later calcite, are formed during water subfreezing on the underside. Presence of boxy forms on gypsum crystals, as well as presence of different isomorphic impurities $(\mathrm{Mg}, \mathrm{Sr}, \mathrm{Na})$ in calcite reflect relatively quick disordered crystallization associated with strong saturation caused 
by water layer frosting and accumulation of salts in the liquid phase. Emergence of gaylussite reflects conditions of mineralization close to cryogenic.

Calcite pellicles crystallize on the lakes of warm zone, which formation is associated with evaporation of carbon dioxide and formation of a zone of supersaturation with calcium carbonate in the near-surface layer of water. Formation of a dense calcite crust contributes to micro-reservoirs on its uneven surface, which water evaporation and minerals deposition is involved like deposition of salts in arid climates.

Despite the same initial chemical composition of solutions formed during infiltration through the carbonate-sulphate massif, the specific sequence of minerals crystallization on the water surface is typical for different climatic zones. Detected difference is associated with different phase-climatic conditions and mechanisms of supersaturated solutions.

In contrast to the known typical cryogenic minerals (Andreychuk \& Galuskin 2001; Tchaikovskiy \& Kadebskaya 2009) associated with shock crystallization in the thin pellicle of water on the ice surface, described gypsum crusts from the cold part of the cave are formed in calmer conditions on the expanse of ponds, enriched with salts due to partial freezing. The following mineral indicators of climate are identified: thermophilic dolomite, gypsum and halite, and cryophilic gaylussite.

\section{REFERENCES}

Andreychuk V. \& E. Galuskin, 2001: Cryogenic mineral units of Kungur Ice Cave.- The Pescheri (Caves), Perm, 115-118.

Hill C. \& P. Forti, 1997: Cave minerals of the World. Huntswille, pp. 480.
Tchaikovskiy I. \& O. Kadebskaya, 2009: Cryogenic gypsum of Kungur Ice Cave.- Problems of mineralogy, petrography and metallogeny: Scientific readings memory of the P. Chirvinsky, 12, Perm, 85-90. 